\title{
Identification of marine sponges-symbiotic bacteria and their application in degrading polycyclic aromatic hydrocarbons
}

\author{
ISMAIL MARZUKI ${ }^{1}$, MUDYAWATI KAMARUDDIN ${ }^{2}$, RASHEED AHMAD $^{3, \vartheta}$ \\ 'Department of Chemical Engineering, Faculty of Engineering, Universitas Fajar. Jl. Prof. Abdurahman Basalamah 101, Panakkukang, Makassar 90231, \\ South Sulawesi, Indonesia \\ ${ }^{2}$ Faculty of Health Science, Universitas Muhammadiyah Semarang. Jl. Kedungmundu Raya No. 18, Semarang 50273, Central Java, Indonesia \\ ${ }^{3}$ Department of Biomolecular Engineering, Faculty of Science and Technology, Universitas Airlangga. Jl. Dr. Ir. H. Soekarno, Mulyorejo, Surabaya \\ 60115, East Java, Indonesia. Tel.: +62-31-5936501, Fax.: +62-31-5936502, •email: rasheed.ahmad@ @st.unair.ac.id
}

Manuscript received: 8 December 2020. Revision accepted: xxx February 2021.

\begin{abstract}
Marzuki I, Kamaruddin M, Ahmad R. 2021. Identification of marine sponges-symbiotic bacteria and their application in degrading polycyclic aromatic hydrocarbons. Biodiversitas 22: 1481-1488. Diverse and abundant microbial species that occupy marine sponges may make important contributions to host metabolism. Sponges are filter feeders and devour microorganisms from the seawater around them. Each microbe that endures the sponges' digestive and immune responses are related symbiotically. Marine sponges symbiont bacteria can comprise as much as $40 \%$ of sponge tissue volume, and these are known to exhibit a great potential on polycyclic aromatic hydrocarbons (PAHs) degradation. However, the potential use of marine sponges symbiont bacteria is unexplored. Therefore, we designed and conducted a study to identify bacterial isolates obtained from sponges. For this, we collected sponges samples (Hyrtios erectus, Clathria (Thalysias) reinwardti), Niphates sp., and Callyspongia sp.) from the Spermonde islands in Indonesia. We successfully found eight bacterial isolates from four sponges, as molecular identification based on 16S rRNA approach revealed bacterial isolates of SpAB1, SpAB2, SpBB1, SpDB1, and SpDB2 from three sponges (Hyrtios erectus, Clathria (Thalysias) reinwardti), Niphates sp.). Interestingly, these were closely related to Pseudomonas, and a bacterial isolate from Callyspongia sp. (SpCB1) showed similarity to Bacillus. Bacillus and Pseudomonas bacteria isolated from hydrocarbon-contaminated sponges exhibited degradation of naphthalene and pyrene PAHs.
\end{abstract}

Keywords: Naphthalene, polycyclic aromatic hydrocarbons, pyrene, sponges, sponges-associated bacteria

\section{INTRODUCTION}

Sponges-associated bacteria play a significant role in digestion, waste removal, and chemical defense for the sponge hosts (Taylor et al. 2007). Symbiont and symbiotic words refer to two or more species that have been continuously observed to live together for a long period (Angelard and Bever 2013). In fact, sponge-associated microorganisms are of great interest because of their potential role in producing several compounds (Montalvo and Hill 2011; Moitinho-Silva et al. 2017). Several studies of marine sponges-related bacteria have identified novel bacterial groups, such as the candidate phylum Poribacteria (Lafi et al. 2009). Moreover, bacteria also play a significant role in eliminating polycyclic aromatic hydrocarbons (PAHs) from contaminated habitats but, the potential use of marine sponges with symbiont bacteria is still unexplored (Marzuki 2018).

It is a well-known fact that polycyclic aromatic hydrocarbons that include carcinogenic and mutagenic compounds are dangerous (Khabouchi et al. 2020; Marzuki at al. 2020a) with two or more fused benzene rings that originate from both natural sources and anthropogenic activities. Generally, PAHs are ubiquitously distributed on the Earth and the Sea (Bendouz et al. 2017). The marine environment is the most vulnerable region to PAHs sludge exposure by human activities and dynamics at sea, a significant threat to marine life (Cajthaml et al. 2008).
Along with industrial growth and the global dynamics of today, the accumulation of PAHs waste into the sea continues because of the contribution of waste from the oil refining industry and marine transport activities (Adkins et al. 2002; Marzuki et al. 2015a). If this condition persists, it may cause serious problems for the lives of different forms of marine life (Marzuki et al. 2015b; Nursid et al. 2017).

Maintaining the protection of the marine environment and the conservation of the growth and production of different marine biota happens naturally, but active human intervention is important because the natural ability of the sea to sustain its ecological balance is very limited due to the massive pollutants that reach the sea (Harpere et al. 2001). Marzuki et al. (2015b) noted that some dramatically exhibit an ability to defend themselves and adapt to the environment and various threatening disturbances; one of which are sponges.

Interestingly, the sponge is a filter feeder by sucking and extracting the sludge, and it provides space for the aggregation of different microorganisms in the sponge body (Lee et al. 2001; Montalvo and Hill 2011; MoitinhoSilva et al. 2017). Melawaty et al. (2014) suggested that marine sponges have bioindicator properties for heavy metals. Their study also indicated that marine sponges symbionts were capable of biodegrading to components of petroleum hydrocarbons (Melawaty et al. 2014). In the context of marine natural resources, the different conditions described above require research that can provide new 
information about the ability of marine biota and other materials that can be used to preserve environmental balance. Research on tracing various marine natural resources, such as mangroves, seagrass, seawater and sediment, as well as sponges and their symbiont bacteria that are potential as biomaterials in the PAHs-type waste biodegradation process (Marzuki et al. 2016).

\section{MATERIALS AND METHODS}

\section{Sponge sample collection, isolation, and purification sponge-symbiotic Bacteria}

The sponge samples were collected from four small islands (Lae-lae, Samalona, Barang Caddi, and Kodingareng Keke) in the administrative area of Makassar city, South Sulawesi Province, Indonesia. These four islands are part of the Spermonde Archipelago area (Figure 1). Sponge $\mathrm{SpA}$ has been obtained around Lae-lae Island, sponge $\mathrm{SpB}$ around the island of Samalona, sponge $\mathrm{SpC}$ around Barrang Caddi Island, and sponge SpD has been obtained around Kodingareng Keke Island. Sampling locations have been documented as a basis for geographic distributions (Marzuki et al. 2020c). The position of the coordinates, the ecological, and physical characteristics of each sponge was provided in Table 1.

Thus, the sponge samples were directly grouped and marked by location at which they were collected. Mesohyl portion of each sponge was taken $1 \times 1$ centimeter in size, washed with 5 milliliters of sterilized seawater, crushed, and diluted with 1:1 sterilized Phosphate Buffer Saline (PBS) ration (Trindade-Silva et al. 2012). Spongeassociated Bacteria were isolated by using a sterilized swab which was rubbed into one direction on the outer surface of the sponge (Taylor et al. 2007). The sterilized swab was then placed in a dilution tube that contained sterilized PBS and vortexed. The dilution results $(1 \mathrm{~mL})$ were spread on a petri-dish containing Sea Water Complete (SWC) media. Bacterial colonial growth was observed for 24-36 hours at $26^{\circ} \mathrm{C}$ by analyzing colony morphology (shape, color, cell distribution, and endospore). The bacteria which grew were then purified on SWC media for 1-2 weeks (Yetti et al. 2015). For each colony grown on the SWC media, transferred to Marine Agar (MA) media and incubated for 1-2 days at $30^{\circ} \mathrm{C}$. The same procedure applied to new colonies growing up till getting a single colony (Zafra et al. 2016; Medic et al. 2020).
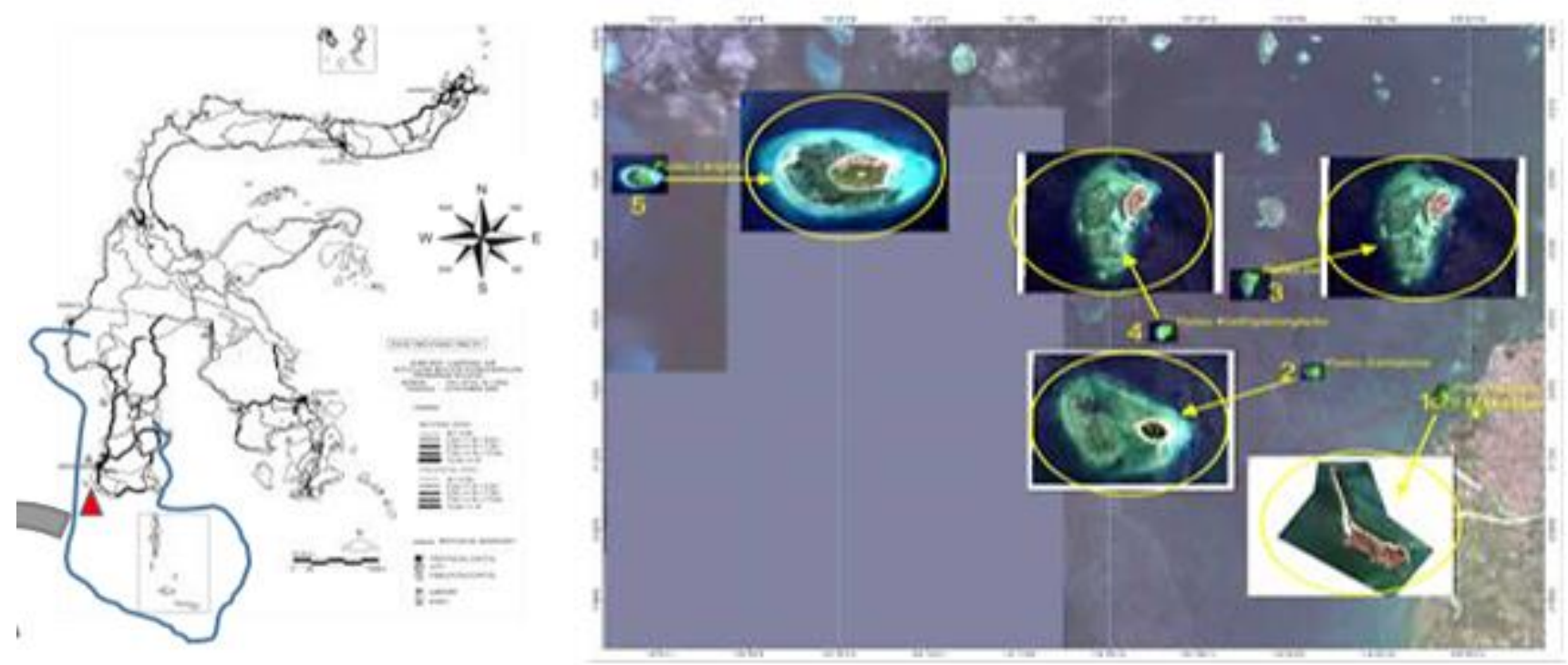

Figure 1. Location of sponge sampling points on four small islands as part of the Spermonde Archipelago area. Point 1. Lae-lae Island

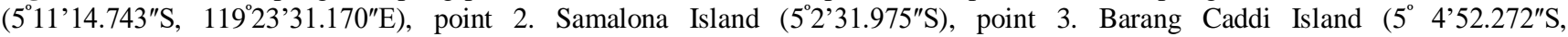
$\left.119^{\circ} 19^{\prime} 14.376^{\prime \prime} \mathrm{E}\right)$, and point 4. Kodingareng Keke Island (5 6’21.423"S, $\left.119^{\circ} 17^{\prime} 19.399^{\prime \prime} \mathrm{E}\right)$

Table 1. Data of collected sponges and sampling points

\begin{tabular}{lllccc}
\hline \multicolumn{1}{c}{ Sponges } & \multicolumn{1}{c}{ Location } & Surface & Altitude (m) & Latitude & Longitude \\
\hline Hyrtios erectus & Lae-lae Island & Rough & 4.2 & $5^{\circ} 11^{\prime} 14.743^{\prime \prime} \mathrm{S}$ & $119^{\circ} 23^{\prime} 31.170^{\prime \prime} \mathrm{E}$ \\
Clathria & Samalona Island & Rough & 4.8 & $5^{\circ} 2^{\prime} 31.975^{\prime \prime} \mathrm{S}$ & $119^{\circ} 20^{\prime} 37.061^{\prime \prime} \mathrm{E}$ \\
Niphates sp. & Barang Caddi Island & Smooth & 3.9 & $5^{\circ} 4^{\prime} 52.272^{\prime \prime} \mathrm{S}$ & $119^{\circ} 19^{\prime} 14.376^{\prime \prime} \mathrm{E}$ \\
Callyspongia sp. & Kodingareng Keke Island & Smooth & 4.6 & $5^{\circ} 6^{\prime} 21.423^{\prime \prime} \mathrm{S}$ & $119^{\circ} 17^{\prime} 19.399^{\prime \prime} \mathrm{E}$ \\
\hline
\end{tabular}




\section{Sponge-symbiotic bacteria phenotype analysis}

The mesohyl portion of each sponge was cut crosssectional immediately after the sponge was immersed in $70 \%$ methanol, and observed under a hemocytometer phase-contrast microscope. The sponge sample was crushed in a blender, then the suspension was analyzed using a hemocytometer phase-contrast microscope to see the types of cells, and skeletons sponges (Ismet et al. 2011; Marzuki et al. 2016). Phenotype analysis of symbiont bacteria was carried out using bacterial isolates biochemical test applied a typical biochemical reagent assay (Kurniawan 2012). Gram stain method (Nguyen and Thomas 2018), and the results were observed under a 10x magnification microscope.

\section{DNA extraction, PCR, and sequencing analysis}

Genomic DNA was extracted from symbiont bacterial isolates using the DNAzol® reagent (Thermo Fisher Scientific, Waltham, MS, USA) according to the manufacturer's instructions with some modifications (Kamaruddin et al. 2014). Total DNA of extracted symbionts was amplified with universal primers of $16 \mathrm{~S}$ rRNA gene with forward sequence was 5'CCAGCAGCCGCGGTAATACG 3' attached to the nucleotide base of 518-537, and reverse sequence was 5'ATCGG(C/T)TACCTTGTTACGACTTC 3' attached to the nucleotide base of 1513-1491 (Kamaruddin et al. 2020; Marzuki et al. 2020; Minarti et al. 2020). The PCRs were performed in a final volume of $20 \mu \mathrm{l}$ using DreamTag buffer (Fermentas, MA), approximately $1 \mu \mathrm{g}$ of genomic DNA as templates, each primer at $0.2 \mu \mathrm{M}$, each deoxynucleoside triphosphate (dNTP) at $2.5 \mathrm{mM}$ and 2.5 $\mathrm{mM}$ enzyme under the following condition: a denaturation step of $94^{\circ} \mathrm{C}$ for $1 \mathrm{~min}$ followed by 30 cycles of $95^{\circ} \mathrm{C}$ for 5 min, annealing at $54^{\circ} \mathrm{C}$ for $1 \mathrm{~min} 20$ seconds, and extension at $72^{\circ} \mathrm{C}$ for $2 \mathrm{~min}$. The post-extension was completed at $72^{\circ} \mathrm{C}$ for $10 \mathrm{~min}$. The target bands were then excised from the gel and purified using the FastGene ${ }^{\circledR}$ gel/PCR extraction kit (Nippon Genetics, Tokyo, Japan) according to the manufacturer's instructions. The direct sequencing of each purified PCR product was conducted with the ABI Prism BigDye ${ }^{\circledR}$ Terminator v3.1 Cycle Sequencing Kit (Life Technologies Japan, Tokyo, Japan) on an Applied Biosystems 3130 Genetic Analyzer (Life Technologies). All nucleotide sequences were confirmed using both the forward and reverse reading data, and ambiguous nucleotides were precisely confirmed by conducting the sequencing procedure repeatedly.

\section{Phylogenetic analysis and nucleotide sequence accession numbers}

In total 9 reference sequences of the $16 \mathrm{~S}$ rRNA region of marine sponge symbiont bacteria were obtained from the NCBI GenBank, and analyzed using ClustalW (Rua et al. 2018). The phylogenetic reconstruction was conducted using the neighbor-joining method with MEGA 6 (Tamura et al. 2013) based on the multiple sequence alignments, and the bootstrap statistical value was calculated with 1,000 replications to estimate the reliability of the tree. The newly identified sequences of $16 \mathrm{~S}$ rRNA region were deposited in the GenBank nucleotide sequence databases under accession numbers of MW025974-MW025979.

\section{Biodegradation activity of sponge-symbiotic bacteria}

Naphthalene and pyrene were the PAHs components used, each in the form of a solution with a $5000 \mathrm{mg} / \mathrm{L}$ concentration (term as PAHs-contaminated waste). The isolated bacteria cells used per vial were 2.62 to $3.45 \times 10^{4}$ (based on the turbidity of bacterial suspension and PAHs), thus they were suspended with a $0.9 \%$ physiological $\mathrm{NaCl}$ solution, then $10 \mathrm{~mL}$ were applied to each $50 \mathrm{~mL}$ falcon tubes which were adapted by 1 x 24 hours of incubation. Add $2 \mathrm{~mL}$ of PAHs-contaminated waste for each falcon tubes. The interaction between bacterial suspension and PAHs-contaminated waste was maximized at $100 \mathrm{rpm}$, room temperature, and 15-day incubation by aeration with a shaker incubator. Each treatment was repeated 3 times. The parameters for biodegradation were observed and recorded every 3 days (Taylor et al. 2007; Marzuki et al. 2015b; Pawar and Al-Tawaha 2017).

\section{RESULTS AND DISCUSSION}

\section{Sponge symbiont bacteria isolation}

We isolated 14 bacterial isolates from 4 types of mesohyl sponges that collected from different islands of the Spermonde Archipelago area, Makassar district (South Sulawesi province, Indonesia).

Among the initially bacterial isolated, only limited isolates such as two bacterial isolates from sponge $\mathrm{SpA}$ (SpAB1; SpAB2), a SpB sponge bacterial isolate (SpBB1), a $\mathrm{SpC}$ sponge bacterial isolate $(\mathrm{SpCB} 1)$, and $\mathrm{SpD}$ sponge bacterial isolates (SpDB1; SpDB2). Additionally, some reference $16 \mathrm{~S}$ sequences that were added in the phylogenetic analysis have been identified through direct sequencing of the $16 \mathrm{~S}$ rRNA gene.

\section{Morphology and phenotype analysis of sponge- symbiotic bacteria}

Depending on the host where the bacteria did symbiosis, the morphological examination of bacteria collected from sponges has remarkable differences. Morphology (shape, color, cell distribution, and endospore) analysis of bacterial isolates (SpAB1 and SpAB2) from sponge SpA showed similar morphology. They were rounded in shape, bluish beige color, clustered distribution, and their endospores were invisible. The SpB sponge symbiont bacteria have similarities in the form of serrated stem, brown color, separated distribution. However, the endospore was less visible in SpBB1 isolate, while the endospore was visible in $\mathrm{SpBB} 2$ isolate. The bacteria SpCB1 and SpCB2 isolates have morphological differences from each other. Isolate $\mathrm{SpCB} 1$ had such a serrated rod and brown color. Meanwhile, the isolate SpCB2 was slightly round in shape and bluish color. The two isolates, however, had endospores and clustered-distribution (Marzuki 2018). Equally, with sponge $\mathrm{SpD}$, both $\mathrm{SpDB} 1$ and $\mathrm{SpDB} 1$ 
bacterial isolates had the same shape and color (round and brown), but differed in cell distribution and availability of endospores. Isolate SpDB1 was distributed separately and the endospore was less visible, while isolate SpDB2 was clustered and the endospore was clear. The Gram stain test revealed that 5 isolates $(\mathrm{SpBB} 2, \mathrm{SpCB} 1, \mathrm{SpCB} 2, \mathrm{SpDB} 1$, and SpDB2) of the sponge symbiont bacteria were Grampositive (+), and the remaining 3 isolates (SpAB1, SpAB2, and SpBB1) were Gram-negative (-) (Table 2).

Sponge-symbiotic bacteria phenotype analysis used standard biochemical reagents with fourteen types of activity test reactions were presented in Table 3.

\section{Identification and phylogenetic analysis of sponge symbiont bacteria}

Among the 14 sponge-symbiotic bacteria isolated in this study, only 6 bacterial isolates (948-955 bp) were identified phylogenetically (Figure 2) revealed that bacterial isolates of SpAB1, SpAB2, SpBB1, SpDB1 and SpDB2 from three sponges: Hyrtios erectus, Clathria
(Thalysias reinwardti), Niphates sp. were closely related to Pseudomonas, one bacterial isolated from Callyspongia sp. (SpCB1) showed similarity to Bacillus.

\section{Biodegradation activity of sponge-symbiotic bacteria}

Several types of sponge-symbiotic bacterial isolates have been tested for PAHs biodegradation activity on a laboratory scale. Waste modified with PAHs of the form naphthalene (2-ring aromatic) and pyrene (4-ring aromatic) were prepared separately. Biodegradation of $\mathrm{PAH}$ components by bacterial suspension by immediate contact with naphthalene and pyrene in liquid water, each with a concentration of $5000 \mathrm{mg} / \mathrm{L}$ for 15 days in falcon tubes. Biodegradation parameters, as shown in Tables 4 and 5, which air bubbles or gas, the odor of fermentation were typical of fermentation reactions as an indication of the breakdown of the molecular structure of $\mathrm{PAH}$ (Naphthalene/Pyrene) resulting in degradation products in the form of basic organic compounds and $\mathrm{CO}_{2}$ gas.

Table 2. Morphology analysis and Gram staining test of sponge-symbiotic bacteria

\begin{tabular}{lcll}
\hline $\begin{array}{c}\text { Sponge } \\
\text { Species }\end{array}$ & $\begin{array}{c}\text { Symbiont } \\
\text { bacteria isolates }\end{array}$ & \multicolumn{1}{c}{ Morphology of Sponge-symbiotic bacteria } & $\begin{array}{c}\text { Gram staining } \\
\text { test }\end{array}$ \\
\hline SpA & SpAB1 & Rounded shape, bluish beige color, clustered distribution, less visible endospore & Gram-negative (-) \\
& SpAB2 & Slightly round-shape, bluish beige color, clustered distribution, less visible endospore & Gram-negative (-) \\
SpB & SpBB1 & Serrated stem-shape, brown color, separated distribution, less visible endospore & Gram-negative (-) \\
& SpBB2 & Serrated stem-shape, brown color, separated distribution, visible endospore & Gram-positive (+) \\
SpC & SpCB1 & Serrated stem-shape, brown color, clustered distribution, visible endospore & Gram-positive (+) \\
& SpCB2 & Slightly round-shape, bluish color, clustered distribution, visible endospore & Gram-positive (+) \\
SpD & SpDB1 & Round-shape, brown color, separated distribution, less visible endospore & Gram-positive (+) \\
& SpDB2 & Round-shape, brown color, clustered distribution, visible endospore & Gram-positive (+) \\
\hline
\end{tabular}

Table 3. Characterization of marine sponge-symbiotic bacteria using biochemical research approach

\begin{tabular}{|c|c|c|c|c|c|c|c|c|c|}
\hline \multirow{2}{*}{ Biochemical reagents } & \multirow{2}{*}{ Media } & \multicolumn{8}{|c|}{ Sponge symbiont bacteria } \\
\hline & & SpAB1 & SpAB2 & SpBB1 & SpBB2 & SpCB1 & SpCB2 & SpDB1 & SpDB2 \\
\hline Starch Hydrolysis & starch agar & basic & basic & basic & basic & basic & basic & basic & basic \\
\hline Casein Hydrolysis & milk agar & acidic & acidic & acidic & acidic & acidic & acidic & acidic & acidic \\
\hline Gelatin Hydrolysis & nut. gelatin & - & - & - & - & + & + & - & - \\
\hline Nitrate reduction & nitrate broth & - & - & - & - & - & - & - & - \\
\hline Indole & tryptone broth & - & + & - & - & + & - & - & - \\
\hline $\mathrm{H}_{2} \mathrm{~S}$ & $\mathrm{H}_{2} \mathrm{~S}$ agar & - & - & + & - & + & - & - & - \\
\hline Red Methyl & R-VP broth & + & - & + & + & + & + & + & + \\
\hline Voges-Proskauer & R-VP broth & + & + & + & + & + & + & + & + \\
\hline Citric & CSA & + & + & - & - & + & + & - & - \\
\hline Urease & urea broth & - & - & + & - & - & - & - & - \\
\hline Glucose & glucose catalase & - & - & - & - & - & - & - & - \\
\hline Lactose & lactose catalase & + & + & - & + & + & + & + & + \\
\hline Sucrose & sucrose catalase & - & + & - & - & - & - & - & - \\
\hline Mannitol & mannitol catalase & - & - & - & - & - & - & - & - \\
\hline
\end{tabular}

Note: (+) indicates there is a reaction, (-) means no reaction 


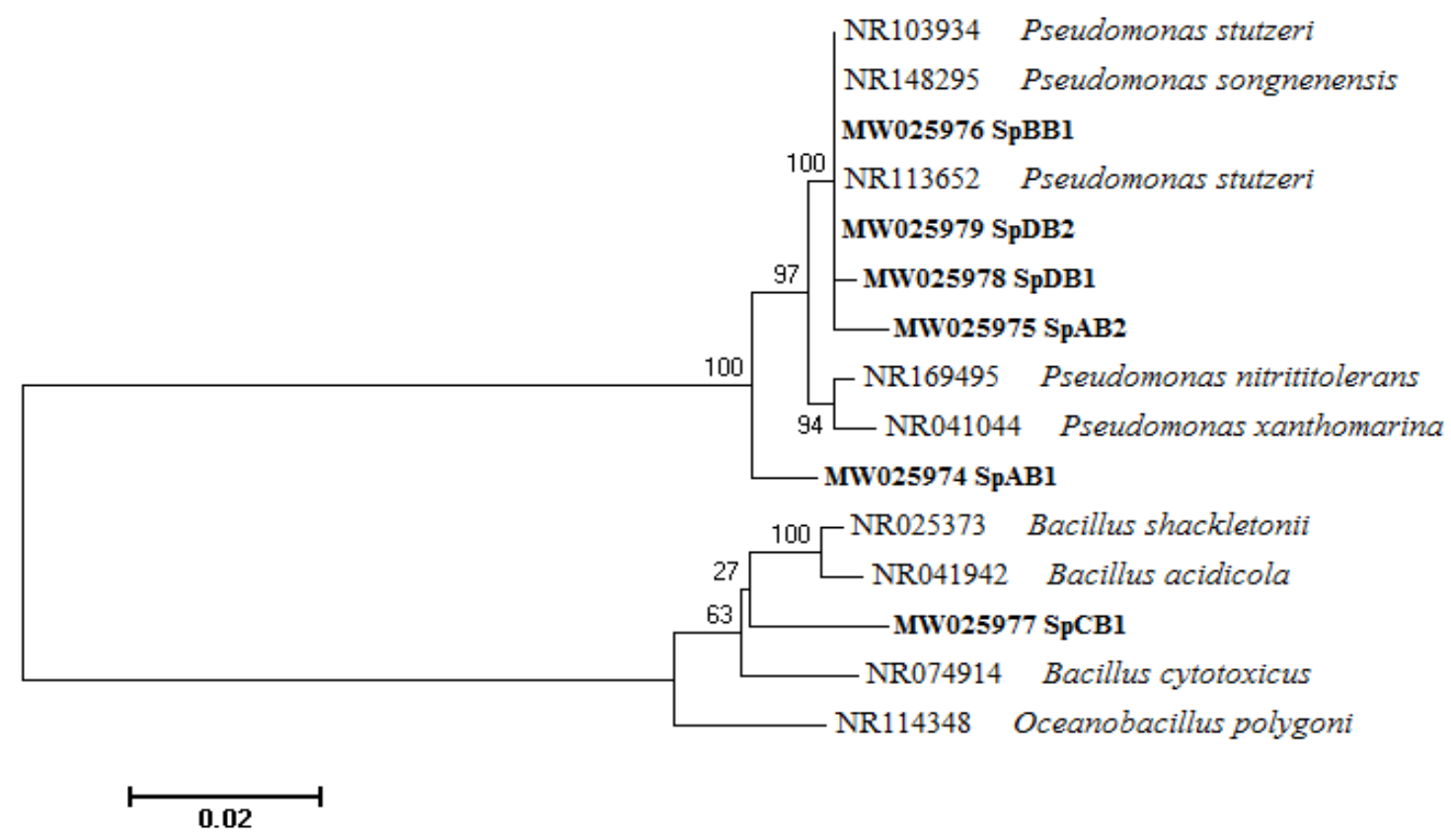

Figure 2. Representative neighbor-joining tree reconstructed with the 16S rRNA sequences of marine sponge symbiont bacteria

Table 4. Sponge-symbiotic bacteria activity of modified-naphthalene waste

\begin{tabular}{|c|c|c|c|c|c|c|c|c|c|}
\hline \multirow{2}{*}{$\begin{array}{c}\text { Biodegradation } \\
\text { parameters }\end{array}$} & \multirow{2}{*}{$\begin{array}{c}\text { Contact time } \\
\text { (days) }\end{array}$} & \multicolumn{8}{|c|}{ Interaction between sponge symbiont bacteria and anthracene } \\
\hline & & SpAB1 & SpAB2 & SpBB1 & SpBB2 & SpCB1 & SpCB2 & SpDB1 & SpDB2 \\
\hline Optical density & $0 \mathrm{~d}$ & 0.062 & 0.069 & 0.071 & 0.067 & 0.072 & 0.062 & 0.068 & 0.073 \\
\hline (absorbance $\lambda: 600 \mathrm{~nm}$ ) & $15 \mathrm{~d}$ & 0.212 & 0.176 & 0.163 & 0.343 & 0.373 & 0.434 & 0.483 & 0.356 \\
\hline $\mathrm{pH}$ & $0 \mathrm{~d}$ & 7.0 & 7.1 & 7.0 & 7.1 & 7.1 & 7.0 & 7.1 & 7.1 \\
\hline & $15 \mathrm{~d}$ & 6.9 & 6.8 & 6.7 & 6.5 & 6.2 & 5.9 & 5.9 & 6.3 \\
\hline Air bubble & $0 \mathrm{~d}$ & - & - & - & - & - & - & - & - \\
\hline & $15 \mathrm{~d}$ & $\sqrt{ }$ & $\sqrt{ }$ & $\sqrt{ }$ & $\sqrt{ }$ & $\sqrt{ } \sqrt{ }$ & $\sqrt{ } \sqrt{ }$ & $\sqrt{ } \sqrt{ }$ & $\sqrt{ } \sqrt{ }$ \\
\hline Fermented flavor & $0 \mathrm{~d}$ & - & - & - & - & - & - & - & - \\
\hline & $15 \mathrm{~d}$ & $\Delta$ & $\Delta$ & $\Delta$ & $\Delta$ & $\Delta \Delta$ & $\Delta \Delta$ & $\Delta \Delta$ & $\Delta \Delta$ \\
\hline Activity & $0 \mathrm{~d}$ & - & - & - & - & - & - & - & - \\
\hline & $15 \mathrm{~d}$ & ++ & + & + & ++ & +++ & +++ & +++ & ++ \\
\hline
\end{tabular}

Note: $\sqrt{ }$ : there are a few air bubbles forming, $\sqrt{ } \sqrt{ }$ : a lot of air bubbles forming, $\Delta$ : fermentation flavor was not strong, $\Delta \Delta$ : fermentation flavor was strong, +: low biodegradation activity, ++: moderate biodegradation activity, +++: strong biodegradation activity

Table 5. Sponge-symbiotic bacteria activity of modified-pyrene waste

\begin{tabular}{|c|c|c|c|c|c|c|c|c|c|}
\hline \multirow{2}{*}{$\begin{array}{c}\text { Biodegradation } \\
\text { parameters }\end{array}$} & \multirow{2}{*}{$\begin{array}{l}\text { Contact time } \\
\text { (days) }\end{array}$} & \multicolumn{8}{|c|}{ Interaction between sponge symbiont bacteria and pyrena } \\
\hline & & SpAB1 & SpAB2 & SpBB1 & SpBB2 & SpCB1 & SpCB2 & SpDB1 & SpDB2 \\
\hline Optical density & $0 \mathrm{~d}$ & 0.065 & 0.063 & 0.075 & 0.071 & 0.072 & 0.064 & 0.069 & 0.071 \\
\hline (absorbance $\lambda: 600 \mathrm{~nm}$ ) & $15 \mathrm{~d}$ & 0.112 & 0.102 & 0.113 & 0.262 & 0.311 & 0.351 & 0.326 & 0.274 \\
\hline $\mathrm{pH}$ & $0 \mathrm{~d}$ & 7.1 & 7.0 & 7.0 & 7.0 & 7.0 & 7.0 & 7.0 & 7.1 \\
\hline & $15 \mathrm{~d}$ & 6.9 & 6.9 & 6.9 & 6.8 & 6.6 & 6.3 & 6.4 & 6.5 \\
\hline Air bubble & $0 \mathrm{~d}$ & - & - & - & - & - & - & - & - \\
\hline & $15 \mathrm{~d}$ & $\sqrt{ }$ & - & - & - & $\sqrt{ }$ & $\sqrt{ }$ & $\sqrt{ } \sqrt{ }$ & $\sqrt{ }$ \\
\hline Fermented flavor & $0 \mathrm{~d}$ & - & - & - & - & - & - & - & - \\
\hline & $15 \mathrm{~d}$ & $\Delta$ & - & - & $\Delta$ & $\Delta$ & $\Delta$ & $\Delta \Delta$ & $\Delta$ \\
\hline Activity & $0 \mathrm{~d}$ & - & - & - & - & - & - & - & - \\
\hline & $15 \mathrm{~d}$ & + & + & - & + & ++ & ++ & +++ & ++ \\
\hline
\end{tabular}

Note: $\sqrt{ }$ : there are a few air bubbles forming, $\sqrt{ }$ : a lot of air bubbles forming, $\Delta$ : fermentation flavor was not strong, $\Delta \Delta$ : fermentation flavor was strong, +: low biodegradation activity, ++: moderate biodegradation activity, +++: strong biodegradation activity 

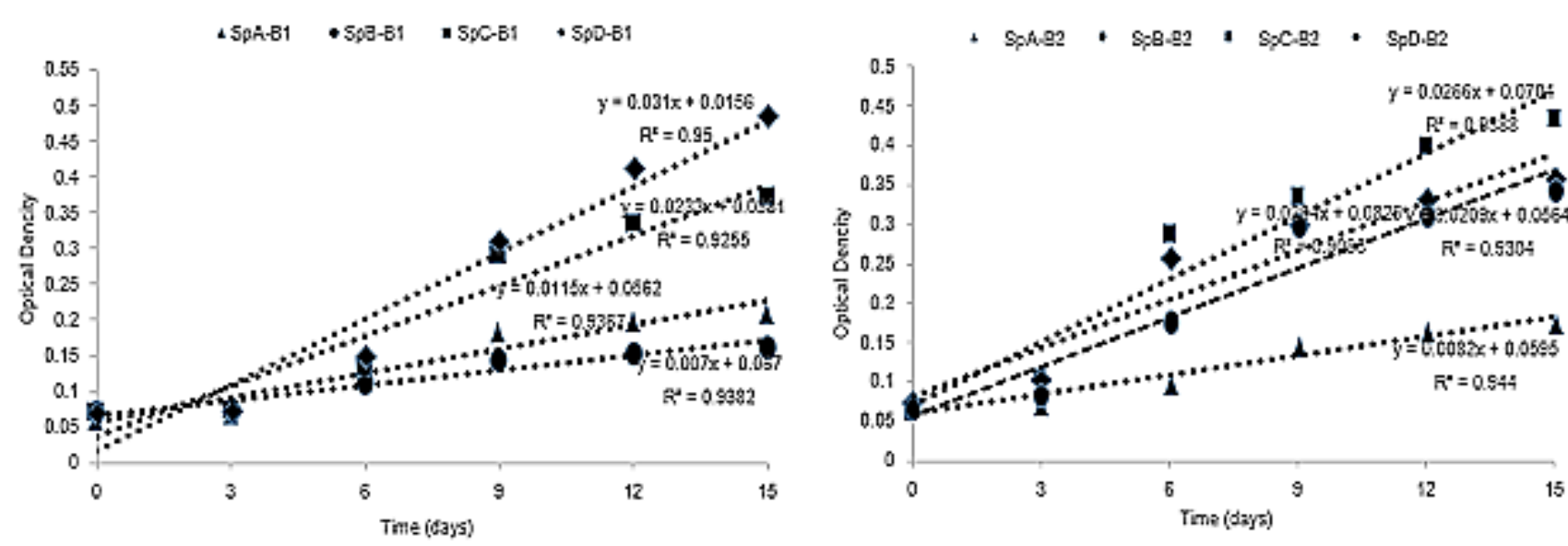

A
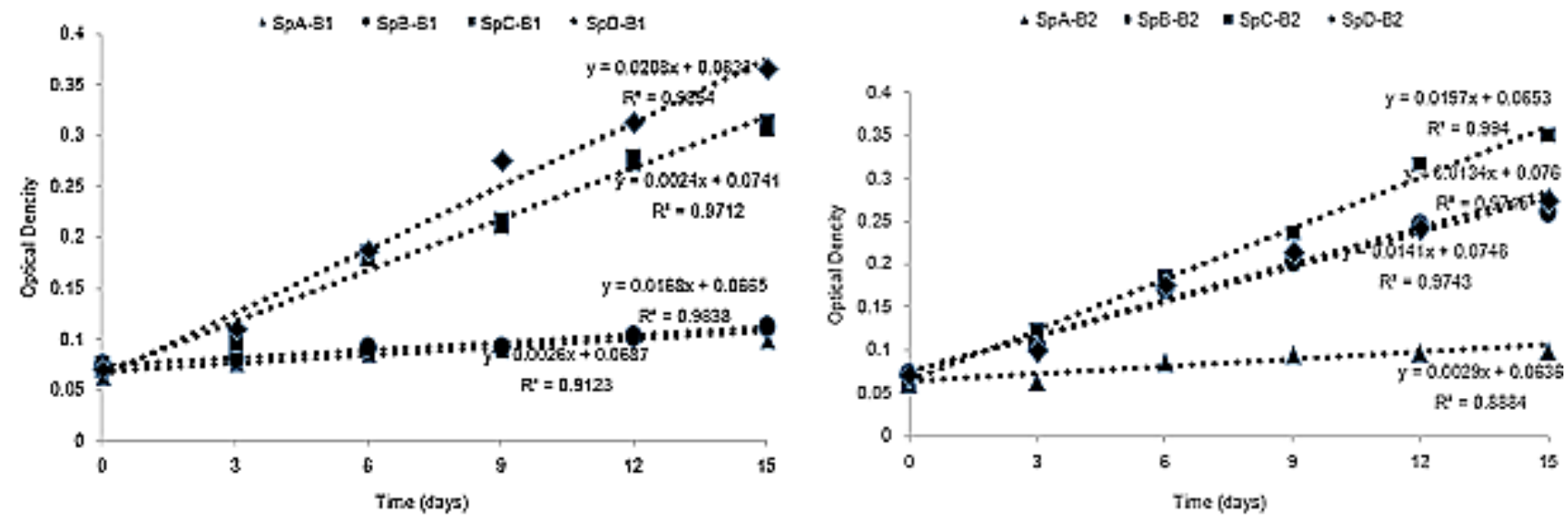

B

Figure 3. Biodegradation activity of sponge symbiont bacteria against PAHs. A. Activity of sponge symbiont bacteria isolates on Naphthalene; B. Activity of sponge symbiont bacteria isolates on Pyrene

In particular, the media become more acidic by measuring the $\mathrm{pH}$ of the media using the $\mathrm{pH}$ universal indicator paper. In order to determine the type of simple organic compounds biodegradation products of the bacteria against Naphthalene/Pyrene, it should be measured using GC-MS so that the abundance of PAH is determined if it has decreased or is constant and can also determine the type of organic compounds formed by biodegradation. Suggested that all bacterial isolates have biodegradation activity against naphthalene and pyrene, but vary in frequency of activity.

The bacterial isolates of SpCB1, SpCB2 and SpDB1 were found to have the highest biodegradation activity against naphthalene compared to other isolates. While biodegradation activity against pyrene was the strongest suggested by SpDB1 isolate.

\section{Discussion}

The identification of marine sponge-symbiotic bacteria has done in this study showed that morphology and Gram staining of each bacteria is different depending on the host where the bacteria did symbiosis. This can be used as a reference to the biodegradation of polycyclic aromatic hydrocarbons by these marine sponge symbionts. Marzuki et al. (2015a; 2020b) has developed morphological analysis and Gram stain tests of sponge-symbiotic bacteria to determine if there is a relationship between the morphology of bacteria and the activity of PAH biodegradation (Marzuki et al. 2015b; Marzuki et al. 2020a). Phenotype data for sponge-symbiotic bacteria is also one of the variables that can be used as a reference in the tracking of prospective bacteria for biodegradation of $\mathrm{PAH}$ components in waste. Previous studies by (Ismet et al. 2011; Wang et al. 2018) have explained that bacteria that respond positively to the Methyl Red (MR) reagent are bacteria that ferment glucose into acidic products. If bacteria reacted positively with Voges-Proskauer (VP), it shows that the bacteria have the ability to reduce the molecular structure of simple chemical components based on their ability to ferment butanediol (Akinde and Iwuozor 2012). Another theory reports that the positive reactions of the bacteria to catalase suggest that they have enzymes capable of breaking down peroxides in aerobic metabolism (Marzuki et al. 2015b; Bibi et al. 2016) stated that the positive reactions of the lactose-reactive bacteria indicate that the bacteria are capable of producing enzymes that can 
break down the lactose molecules into glucose (Marzuki et al. 2020b).

Considering the phenotype analysis results on 8 bacterial isolates (Table 4), this information indicates that only 5 isolates (SpBB2; SpCB1, B2; and SpDB1, B2) have the ability to degrade $\mathrm{PAH}$ components. Meanwhile, 3 other isolates $(\mathrm{SpAB} 1, \mathrm{~B} 2$, and $\mathrm{SpBB} 1)$ did not all react positively with MR, VP, catalase, and lactose reagents.

The reconstructed phylogenetic tree of spongesymbiont bacteria 16S rRNA consisted of 3 well-resolved clades supported by moderate bootstrap value shown in Figure 2 that the first clade included SpAB2, SpBB1, SpDB1, B2 that clustered with Pseudomonas stutzeri and Pseudomonas songnenensi with a homology of $97 \%$ to 99\%. The second clade consisted of SpAB1, which was positioned as a daughter clade of the Pseudomonas species. The third clade is SpCB1 that clustered with Bacillus species $(96 \%)$.

This study's findings are very useful in evaluating PAHs biodegradation activity related to phenotypic characteristics of marine sponge symbiont bacteria. Some comparable data, such as morphology, phenotype, and characterization of bacteria should be considered in the search for possible bacteria in PAHs biodegradation (Lloyd et al. 2010; Marzuki et al. 2016). Several factors explain the difference in the biodegradation activity of bacteria to PAHs, including 1) the properties of PAHs with a higher toxicity level of pyrene than naphthalene have an effect on the biodegradability of bacteria; 2) the characteristics and adaptability of bacteria to predators are different; and 3) the number of bacterial cells, the supply of nutrients and oxygen have contributed to the growth, development activity, and strength of the cells (Medić et al. 2020). The amount of bacterial biodegradation activity against PAHs is determined on the basis of the biodegradation parameters. Increasing the optical density of the bacteria in the media indicated that the bacterial cells were growing and evolving. The higher the optical density of the degradation medium, the more bacterial cells that expand and divide. This indicates that sponge-symbiotic bacterial isolates can adapt to naphthalene and pyrene's polluted environment (Figure 3).

Changes in media $\mathrm{pH}$ have been shown to be more acidic, suggesting that bacteria have biodegradation activity against PAHs. The cause of media acidity to increase from the initial stage was due to the contribution of PAH components to the destruction of simple acid organic compounds in biodegradation process. These findings were consistent with previous research (Akinde and Iwuozor 2012), which stated that a simple organic acid compound was one of the products of bacterial biodegradation of hydrocarbons. The increase in the acidity of the biodegradation medium also represents the efficiency of the enzymatic reaction of the bacteria to the PAHs substrate (Marzuki et al. 2015a).

The formation of air bubbles and the fermentation flavor are both unique features and part of the enzyme biodegradation process. In this case, the enzyme was produced by bacteria as a signal for the presence of PAHs toxins. The formation of this enzyme is a bacterial reaction as it protects itself from the toxic material of PAHs. The ability of bacteria to produce enzymes was based on the results of the biochemical tests (Table 4) in which the isolates used in this biodegradation react to multiple reagents ( $\mathrm{Lu}$ et al. 2019).

Based on the data in Tables 4 and 5, it can generally be assumed that the 8 sponge-symbiont bacterial isolates used have biodegradation activity against naphthalene and pyrene, while the strength of their activities differs from each other. Order of strength of biodegradation activity of sponge-symbiont bacteria to naphthalene:

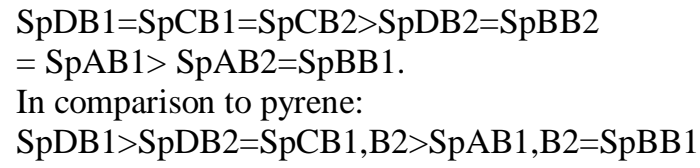

In conclusion, eight marine sponge symbiont bacteria have biodegradable activity against naphthalene and pyrene. The biodegradation activity of bacteria against naphthalene tends to be greater than that of pyrene. There is a tendency for bacteria isolated from sponges with a slimy body surface to have a greater biodegradation activity than bacteria from sponges with clean, and rough body surface regarding sponges from which bacterial isolates were collected. There is, therefore, a relationship between the morphology of the sponge, the features of phenotypic isolation, and the biodegradation strength of PAHs symbiont bacteria.

\section{ACKNOWLEDGEMENTS}

We acknowledge the support of the Ministry of Science and Technology/National Agency for Research and Innovation of the Republic of Indonesia and the Ministry of Education and Culture of the Republic of Indonesia, which support through the Applied Research Grant scheme for 2020 .

\section{REFERENCES}

Adkins JF, Griffin S, Kashgarian M, Cheng H, Lawrence EABR, Shen EC. 2002. Radiocarbon dating of deep-sea corals. Radiocarbon 44 (2): 567-580. DOI: 10.1017/S0033822200031921.

Akinde SB, Iwuozor CC. 2012. Alkane degradative potentials of bacteria isolated from the deep Atlantic Ocean of the Gulf of Guinea. J Bioremediat Biodegrad 3 (1): 1-6. DOI: 10.4172/2155-6199.1000135

Bendouz M, Dionne J, Tran LH, Coudert L, Mercier G, Blais JF. 2017. Polycyclic aromatic hydrocarbon oxidation from concentrates issued from an attrition process of polluted soil using the Fenton reagent and permanganate. Water, Air, Soil Pollut 228 (3): 114-127. DOI: 10.1007/s11270-017-3292-x

Bibi F, Faheem M, Azhar EI, Yasir M, Alvi SA, Kamal MA, Naseer MI. 2016. Bacteria from marine sponges: A source of new drugs. Curr Drug Metab 18: 11-15. DOI: 10.2174/13892002176661610130906.

Cajthaml T, Erbanova P, Kollmann A, Novotny C, Sasek V, Cajthaml T, Sasek V. 2008. Degradation of PAHs by ligninolytic enzymes of Irpex lacteus. Folia Microbiol 53 (4): 289-294. DOI: 10.1007/s12223008-0045-7.

Ismet MS, Soedharma D, Effendi H. 2011. Morfologi dan biomassa sel spons Aaptos aaptos dan Petrosia sp. Jurnal Ilmu dan Teknologi Kelautan Tropis 3 (2): 153-161. DOI: 10.28930/jitkt.v3i2.7829. [Indonesia] 
Kamaruddin M, Tokoro M, Moshiur RM, Arayama S, Hidayati APN, Syafruddin D, Kawahara E. 2014. Molecular characterization of various trichomonad species isolated from humans and related mammals in Indonesia. Korean J Parasitol 52 (5): 471-478. DOI: 10.3347/kjp.2014.52.5.471.

Kamaruddin, Mudyawati, Triananinsi N, Sampara N, Sumarni, Minarti, Maya ARA. 2020. Karakterisasi DNA Mikrobiota Usus Bayi pada Persalinan Normal yang diberi ASI dan Susu Formula. Media Kesehatan Masyarakat 16 (1): 116-126. DOI: http://dx.doi.org/10.30597/mkmi.v16i1.9050. [Indonesia]

Khabouchi I, Khadhar S, Driouich CR, Chekirbene A, Asia L, Doumen P. 2020. Study of organic pollution in superficial sediments of Meliane river catchment area: aliphatic and polycyclic aromatic hydrocarbons. Environ Monit Assess 192 (5): 283. DOI: 10.1007/s10661-020-8213-6.

Kurniawan A. 2012. The isolation and identification of petrofilic bacteria from Total Petroleum Hydrocarbons (Tph) residues under $1 \%(\mathrm{~W} / \mathrm{W})$ of bioremediation process results. In: Prosiding Seminar Nasional Waste Management I. Surabaya, 21 February 2012. [Indonesia]

Lafi FF, Fuerst JA, Fieseler L, Engels C, Goh WWL, Hentschel U. 2009. Widespread distribution of Poribacteria in Demospongiae. Applied Environ Microbiol 75 (17): 5695-5699. DOI: 10.1128/AEM.00035-09

Lee YK, Lee JH, Lee HK. 2001. Microbial symbiosis in marine sponges. J Microbiol 39 (4): 254-264.

Lloyd KG, Albert DB, Biddle JF, Chanton JP, Pizarro O, Teske A. 2010. Spatial structure and activity of sedimentary microbial communities underlying a Beggiatoa spp. mat in a Gulf of Mexico hydrocarbon seep. PLoS ONE 5 (1): e8738. DOI: 10.1371/journal.pone.0008738.

Lu C, Hong Y, Liu J, Gao Y, Ma Z, Yang B, Waigi MG. 2019. A PAHdegrading bacterial community enriched with contaminated agricultural soil and its utility for microbial bioremediation is. Environ Pollut 251: 773-782. DOI: 10.1016/j.envpol.2019.05.044

Marzuki I, Chaerul M, Erniati, Asmeati, Paserangi I. 2020a Biodegradation of aliphatic waste components of oil sludge used micro symbiont of Sponge Niphates sp. IOP Conf Ser: Earth Environ Sci 429 (1): 012056. DOI: 10.1088/1755-1315/429/1/012056.

Marzuki I, Daris L, Nisaa K, Emelda A. 2020b. The power of biodegradation and bio-adsorption of bacteria symbiont sponges sea on waste contaminated of polycyclic aromatic hydrocarbons and heavy metals. IOP Conf Ser: Earth Environ Sci 584: 012013. DOI: 10.1088/1755-1315/584/1/012013

Marzuki. 2018. Eksplorasi Spons Indonesia: Sekitar Kepulauan Spermonde. Nas Media Pustaka, Makassar.

Marzuki I, Daris L, Yunus S, Riana AD. 2020c. Selection and characterization of potential bacteria for polycyclic aromatic biodegradation of hydrocarbons in sea sponges from Spermonde Islands, Indonesia. AACL Bioflux 13 (6): 3493-3506.

Marzuki I, Noor A, Nafie NL, Djide MN. 2015a. Sponge role in alleviating oil pollution through sludge reduction, a preliminary approach. Intl J Appl Chem 11 (4): 427-441.

Marzuki I, Noor A, Nafie NL, Djide MN. 2015b. The potential biodegradation hydrocarbons of petroleum sludge waste by cell biomass sponge Callysppongia sp. Marina Chimica Acta 16 (2): 1120. DOI: $10.20956 /$ mca.v16i2.7407.

Marzuki1 I, Noor A, Nafie NL, Djide MN. 2016. Microsymbiont and morphological phenotype analysis marine sponge. Marina Chimica Acta 17 (1): 1-8. DOI: 10.17605/OSF.IO/P73EN.
Medić A, Lješević M, Inui $\mathrm{H}$, Beškoski V, Kojić I, Stojanović K, Karadžić I. 2020. Efficient biodegradation of petroleum: N -alkanes and polycyclic aromatic hydrocarbons by polyextremophilic Pseudomonas aeruginosa san ai with multidegradative capacity. RSC Adv 10 (24): 14060-14070. DOI: 10.1039/c9ra10371f.

Melawaty L, Noor A, Harlim T, de Voogd N. 2014. Essential metal Zn in sponge Callyspongia aerizusa from Spermonde Archipelago. Adv Biol Chem 4 (1): 86-90. DOI: 10.4236/abc.2014.41012.

Minarti, Triananinsi N, Sampara N, Sumarni Kamaruddin M. 2020. Metagenomic diversity of gut microbiota of gestational diabetes mellitus of pregnant women. Jurnal Biomedika 13 (1): 1-8. DOI: DOI: $10.31001 /$ biomedika.v13i1.747.

Moitinho-Silva L, Nielsen S, Amir A, Gonzalez A, Ackermann GL, Cerrano C, Thomas T. 2017. The sponge microbiome project. GigaSci 6 (10): 1-7. DOI: 10.1093/gigascience/gix077

Montalvo NF, Hill RT. 2011. Sponge-associated bacteria are strictly maintained in two closely related but geographically distant sponge hosts. Appl Environ Microbiol 77 (20): 7207-7216. DOI: 10.1128/AEM.05285-11.

Nguyen MTHD, Thomas T. 2018. Diversity, host-specificity and stability of sponge-associated fungal communities of co-occurring sponges. PeerJ 2018 (6): 1-26. DOI: 10.7717/peerj.4965.

Nursid M, Marasskuranto E, Atmojo KB, Hartono MP, Nur MMD, Riyanti R. 2017. Investigation on antioxidant compounds from marine algae extracts collected from Binuangeun Coast, Banten, Indonesia. Squalen Bull Mar Fishs Postharvest Biotechnol 11 (2): 5967. DOI: $10.15578 /$ squalen.v11i2.243.

Pawar PR, Al-Tawaha ARMS. 2017. Marine sponges as bioindicator species of environmental stress at Uran (Navi Mumbai): West coast of India. Am-Eur J Sustain Agric 11 (3): 29-37.

Rua CPJ, Oliveira LSD, Froes A, Tschoeke DA, Soares AC, Leomil L, Thompson FL. 2018. Microbial and functional biodiversity patterns in sponges that accumulate bromopyrrole alkaloids suggest horizontal gene transfer of halogenase genes. Microb Ecol 76 (3): 825-838. DOI: 10.1007/s00248-018-1172-6.

Tamura K, Stecher G, Peterson D, Filipski A, Kumar S. 2013. MEGA6: Molecular evolutionary genetics analysis version 6.0. Mol Biol Evolut 30 (12): 2725-2729. DOI: 10.1093/molbev/mst197.

Taylor MW, Radax R, Steger D, Wagner M. 2007. Sponge-associated microorganisms: Evolution, ecology, and biotechnological potential. Microbiol Mol Biol Rev 71 (2): 295-347. DOI: 10.1128/mmbr.0004006.

Trindade-Silva AE, Rua C, Silva GGZ, Dutilh BE, Moreira APB Edwards RA, Thompson FL. 2012. Taxonomic and functional microbial signatures of the endemic marine sponge Arenosclera brasiliensis. PLoS ONE 7 (7): 1-10. DOI: 10.1371/journal.pone.0039905.

Wang W, Wang L, Shao Z. 2018. Polycyclic Aromatic Hydrocarbon (PAH) degradation pathways of the obligate marine $\mathrm{PAH}$ degrader Cycloclasticus sp. Strain P1. Appl Environ Microbiol 84 (21): 126118. DOI: 10.1128/AEM.01261-18.

Yetti E, Thontowi A, Lisdiyanti P. 2015. Screening of marine bacteria capable of degrading various polyaromatic hydrocarbons. Squalen Bull Mar Fish Postharvest Biotechnol 10 (3): 121-127. DOI: 10.15578/squalen.v10i3.123.

Zafra G, Regino R, Agualimpia B, Aguilar F. 2016. Molecular characterization and evaluation of oil-degrading native bacteria isolated from automotive service station oil contaminated soils. Chem Eng Trans 49: 511-516. DOI: 10.3303/CET1649086. 